\title{
Service Work in the Pandemic Economy
}

\author{
Aaron Benanav
}

The rapid spread of COVID-19 interacted with long-unfolding economic trends to set a global tinder box aflame. ${ }^{1}$ Over the past thirty years, the world's workforce has increasingly found employment in low-wage, low-productivity jobs in the global services sector. The pandemic lockdowns hit these sorts of activities the hardest. Opportunities to work evaporated, spreading both poverty and hunger around the world. The same rise in global service sector employment shares, which amplified the pandemic lockdown's destructive effects, will now slow the pace of the recovery. The transition to a services-based economy has accelerated, due to what José Antonio Ocampo and Tomasso Faccio call "too much excess capacity and too little certainty about future demand," which have depressed levels of investment and ushered in a period of economic stagnation. ${ }^{2}$ COVID-19 will make these tendencies worse. Weak economic recoveries will further entrench an economic order in which employers pay little attention to workers' demands, deepening employment insecurity and economic inequality. The future for labor looks bleak. What that means for the future of working people remains an open question. Their fight for dignity, in the midst of the pandemic and post-pandemic eras, will prove decisive.

\section{A service-based recession}

The COVID-19 pandemic has caused one of the worst economic downturns in modern history. The World Bank projects a global 6.2 percent decline in income per person in 2020, as well as the first recorded contraction of the Global South economies taken as a whole. ${ }^{3}$ As COVID-19 cases continue to rise around the world, and surge in the most populous countries of the Global South, it seems likely that economic conditions will worsen before they get better. Current estimates model the virus's economic effects as a single shock, but COVID-19 could produce multiple shocks, or endure as a chronic threat. As it stands in summer 2020 , the current recession is already estimated to be more than twice as bad as the Global Financial Crisis of 2008/9. ${ }^{4}$ That is surprising given that, this time around, coordinated central bank action prevented a global financial freeze. Instead of a crisis of finance, the world experienced a crisis of trade, with international trade levels projected to fall by an estimated 20 percent in $2020 .{ }^{5}$ In many countries, the trade shock preceded the virus shock. For most people, this crisis will exceed anything in living memory.

Comparative work on the history of economic downturns helps put the current crisis in a longer-term perspective. In the past 150 years, only three distributed under the terms of the Creative Commons Attribution licence http://creative commons.org/licenses/by/4.0/), which permits unrestricted re-use, distribution, and reproduction in any medium, provided the original work is properly cited. 
worse recessions have been recorded: at the start of the First World War, during the early years of the Great Depression, and following the Second World War. ${ }^{6}$ The Spanish Flu Pandemic occurred during World War I, but there is no other case of pandemic-induced global recession. ${ }^{7}$ Of course, the real source of economic dislocation was not the pandemic itself but the government response to it: states instituted lockdowns without precedent in peacetime. As lockdowns went into effect around the world, a global downturn unfolded that saw more than 90 percent of countries go into recession. ${ }^{8}$ Even the Great Depression left more countries unscathed than the current downturn.

Economic recessions are typically driven by downturns in investment. Consumer services usually stabilize economies that are otherwise contracting, since unlike purchases of consumer goods, purchases of services tend to remain relatively steady over the course of the boom-bust cycle. By contrast, pandemic lockdowns affected services above all. ${ }^{9}$ As spending on services collapsed, and with it, the incomes of many service workers, a decline in consumer demand reverberated through the world's economies, with devastating consequences. The International Labour Organisation (ILO) estimates that in April, May, and June of 2020, 14 percent of all work hours were lost, equivalent to 19.2 billion hours, or 480 million full-time jobs. ${ }^{10}$

\section{A post-industrial workforce}

More people's lives were upended by the 2020 pandemic lockdown than would have been true at any earlier point in history, since many more workers than ever before are employed in services. The downturn's depressive effects on working hours were amplified by a set of long unfolding global transitions, which will continue to shape the future of work worldwide. First, the world's urban population has expanded massively. Since 1970, the urban percentage has risen from 40 to 56 percent. ${ }^{11}$ This small relative increase hides a gigantic change in absolute terms: over the same period, the world's urban population increased from 1.4 to 4.4 billion people. ${ }^{12}$ In most of the world's countries, the prevalence of poor urban housing, often built on squatted land, makes it impossible for populations to self-isolate, since access to water, toilets, and living space has to be shared among many households. ${ }^{13}$

Second, the world's urban transition has been accompanied by a shift in employment structures. In the 1980s, half of the world's laboring population was still engaged in agriculture, much of it traditional farming. ${ }^{14}$ Today, around one quarter remains on the land, although many farming households earn the majority of their incomes from nonfarm activities. Yet, in spite of a global exit from agriculture, the world's industrial employment share has hardly risen. On the contrary, many developing countries, including Mexico, South Africa, and Egypt, deindustrialized "prematurely" after 1980; other countries never industrialized at all. ${ }^{15}$ Worldwide, the industrial employment share has been falling for almost a decade. ${ }^{16}$ 
The result has been a strong increase in service-sector employment, placing much of the world's workforce in precisely the sorts of jobs that have been most affected by the pandemic lockdown. In the richest countries in the world, like the United States and France, services already account for 70 to 80 percent of all employment. ${ }^{17}$ Less well known is that services account for the majority of employment in many Global South countries, such as Brazil and Iran. ${ }^{18}$ In fact, we are either just approaching or have passed the turning point at which services account for half of all employment globally. ${ }^{19}$ Precarious urban workers in the world's low-wage service sector have suffered the most from the pandemic lockdown.

\section{Faulty unemployment statistics}

The world's service-sector based workforce lost work so rapidly in 2020 that it defied the capacities of statistical agencies to measure the severity of the decline. The form that this decline took revealed the weakness of the unemployment rate as a measure of work lost. "Unemployment" has long faced criticisms for its conceptual inadequacy in the face of a precariously employed workforce. ${ }^{20}$ As more workers have been absorbed into nonstandard employment with fewer job protections, the boundary between employment and unemployment has blurred. In 2020, the problem with the unemployment rate was different. Pandemic lockdowns have blurred the boundary between unemployment and economic inactivity. ${ }^{21}$

For example, in the United States, the number of people filing for unemployment benefits each week hit incredible heights once the lockdowns began. Almost seven million workers filed for unemployment in late March 2020 - far higher than any other value yet recorded - with many more millions filing in the weeks that followed. ${ }^{22}$ The unemployment rate jumped from 3.5 percent in February to 14.7 percent in April, yet that was a severe underestimate. ${ }^{23}$ First, the latter figure did not register the large number of workers who kept their jobs but lost hours. Including those workers, the share of the labor force losing work rises to nearly 23 percent. Further distorting the unemployment rate, many people who lost their jobs due to the pandemic officially registered in labor statistics as "inactive" rather than "unemployed," since they were not actively looking for work (at a time when there was clearly no work to be found). Economists at the Federal Reserve estimate the true unemployment rate in April was 30.7 percent, higher than the estimated peak rate of 25 percent recorded in $1933 .^{24}$

In Europe, statistical issues with the unemployment rate took yet another form. States intervened to prevent mass layoffs of workers, rather than to provide unemployed workers with additional cash support. ${ }^{25}$ European workers on furlough continued to receive the majority of their wages but were paid by governments rather than businesses. The unemployment rate in the Eurozone hardly edged upward: from 7.2 percent in February to 7.3 percent in April. ${ }^{26}$ Yet in early May, an estimated 42 percent of workers 
in France and 23 percent in Germany were on furlough. ${ }^{27}$ It is unclear what percentage of European jobs are now "zombie jobs," which continue to exist only because of state support: Allianz estimates that nine million workers, about one fifth of those currently on furlough, will lose their jobs when furlough programs end, causing unemployment rates to spike across the European continent. ${ }^{28}$

\section{The global labor crunch}

At the global level, few workers have access to government assistance, whether in the form of unemployment insurance or furlough payments. Approximately 70 percent of workers in the Global South are so-called "informal" workers; they do not pay into state insurance schemes and receive no benefits in turn. ${ }^{29}$ Statisticians developed the category of economic informality precisely because it was so difficult to get surveys of unemployment to furnish reliable data in this context. ${ }^{30}$ The world's informal workers have largely faced the pandemic storm alone. Their loss of work has been catastrophic. Many poorer households must spend the money they earn each day on the nourishment they need to survive to the next. In Manila, where 70 percent of workers lost their jobs due to the lockdown, incomes shrank by half in April, causing the majority of households to reduce spending on food. ${ }^{31}$

The ILO estimates that worldwide, 1.6 billion informal workers lost 60 percent of their incomes in first months of the coronavirus crisis, reversing decades of poverty reduction and renewing the spread of hunger. ${ }^{32}$ Comparing this 60 percent decline to the 6.2 percent decline the World Bank estimates for the world as a whole gives a sense of how unevenly income loss is being distributed. Populations are going hungry today not because food supply chains have broken down. Workers are simply not earning enough wages to buy the food they need to live. ${ }^{33}$ This is the crisis of a market society that temporarily shut down its markets and largely lacks alternative mechanisms of resource allocation.

The pandemic-led destruction of work has been particularly bad for women, who are overrepresented in activities such as retail trade, which the lockdowns hit hardest. Women are therefore likely suffering from a greater loss of income than men. Compounding this disruption, women have undoubtedly been forced to undertake the majority of the increase in unpaid care work demanded by the pandemic. More than one billion children were estimated to be out of school in Spring 2020. ${ }^{34}$ Especially in poorer countries undergoing demographic transitions (where there are more young children), women assumed an additional burden of care - to which was added the work associated with having other household members spend more time at home and the work involved in taking care of the sick and the dying.

\section{A slow growing world economy}

How long will it take for the world to recover from the pandemic recession, and how will that recovery shape the future of work? Much depends on 
whether it is possible to produce an effective vaccine, as well as on the time required to distribute it globally. Achieving immunity may require frequent booster shots (there is also the dire scenario in which an effective vaccine is never manufactured). ${ }^{35}$ In the meantime, economic recovery hinges on the success of each country in reopening businesses without reigniting the contagion's spread. A range of factors will prove critically important. One is the global financial system's stability, which the extraordinary actions of central banks have so far maintained. Another is the effectiveness of governments' fiscal interventions. As of June 2020, about 10 trillion dollars USD had been spent worldwide to mitigate the crisis (equivalent to 11 percent of global GDP). ${ }^{36}$ However, 88 percent of that total was spent by advanced countries to stabilize their own economies. ${ }^{37}$ Spending in the rest of the world has been lower due to the constraints imposed by previously accumulated public debts, which were higher in 2020 than they had been facing the global financial crisis in $2009 .^{38}$

Past accumulated debts are a sign that the coronavirus crisis did not attack an otherwise healthy economy, which could feasibly bounce back quickly if the pandemic could be contained. On the contrary, the pandemic arrived when the world economy was deeply in trouble. The advanced capitalist countrieswhere public debt levels already approached 100 percent of GDP before the pandemic struck - have been beset by worsening economic stagnation for decades. Organisation for Economic Co-operation and Development (OECD) member states saw average annual economic growth rates slow from 5.7 percent in the 1960 s to 3.6 percent in the $1970 \mathrm{~s}, 3.0$ percent in the $1980 \mathrm{~s}$, 2.6 percent in the 1990 s, and 1.9 percent between 2000 and $2019 .{ }^{39}$ The rapid expansion of the Chinese and Indian economies masked the tendency toward secular stagnation on the global level. However, starting in 2014, those fast growing economies began to slow too, causing global commodity prices to fall and worklessness to rise across the Global South. ${ }^{40}$ Brazil, South Africa, Turkey, and Nigeria were all struggling with rising or persistently high levels of unemployment and underemployment before the 2020 global downturn. ${ }^{41}$

Economies the world over-already facing strong headwinds due to slowing economic growth rates-will now be beset, as well, by the legacies of a global pandemic. As the World Bank emphasizes, COIVD-19 will intensify the "weakness in private investment" that has already "been a feature of the past decade," further depressing economic growth rates worldwide. ${ }^{42}$ What limited evidence there is suggests that pandemics tend to have a long-term, dampening effect on economic growth rates, as sickness leaves legacies of death, loss of income, and accumulated debts. ${ }^{43}$ The implication is that recovery will take a long time.

\section{Overcrowded markets and jobless recoveries}

The increase in the global service-sector employment share, which left so many workers susceptible to losing hours, will make the recovery of those hours more 
difficult to achieve. In a sense, the global economy has proven a victim of its own success. Suppliers in more and more countries have built up productive capacity in agriculture and industry, making for crowded global markets. ${ }^{44}$ As new investments slowed, so too has the growth of employment in agriculture and industry. ${ }^{45}$ Workers the world over have been pushed out of those tradable economic sectors and into nontradable services, which are protected from global competition by their nature. Even countries that appeared to be relatively early in the process of economic development, when taken in isolation, began to deindustrialize prematurely in the 1980s, since those countries were actually part of a larger global economy and were subject to market forces associated with an intense competitive environment (Global South countries were additionally disadvantaged by the imposition of International Monetary Fund-led structural adjustment).

With global industry and agriculture beset by overcapacity, it was increasingly left to services to drive the economy. However, as economist William Baumol explained in the 1960s, services are in large part a stagnant economic sector. ${ }^{46}$ Unlike manufacturing during its heyday, most services do not exhibit dynamic patterns of expansion driven by high rates of labor productivity growth and falling prices. Instead, increases in the demand for services generally depend on spillover effects from productivity-enhancing innovations occurring in other economic sectors. There is a clear link between the global expansion of the stagnant services sector and the ever-worsening stagnation of the wider economy. In the years to come, average economic growth rates will fall further, due to the legacy of the COVID-19 pandemic shock.

The likely outcome is that work in the future will look much like it has in the recent past, only worse. In slow growing economies, the demand for labor is weak. Even when economic contractions officially end, few new jobs are created, leaving all workers in a worse bargaining position vis-a-vis employers. ${ }^{47}$ Under these conditions, workers are forced to accept low wages and poor working conditions as the condition of working at all, making for an economy shaped to an ever greater extent by the whims of business managers and asset owners, without any input from the workers they employ. Businesses have taken advantage of labor's weak bargaining position to build cost-cutting, lean-and-mean global supply chains.

Facing falling tax revenues and higher levels of public debt, governments have engaged in cost-cutting measures as well, periodically visiting austerity on health and education, as well as urban and other social services. ${ }^{48}$ The result, in many countries, has been a reduction in hospital beds, or a failure to invest in them in the first place. Urban housing remains, for many people, poorly constructed, crowded, and ill served. The world economy was not only unprepared for a global pandemic; many countries became less prepared over time, even as rising meat consumption and international travel made a global pandemic like COVID-19 more likely. ${ }^{49}$ A world economy run on a shoe string budget needs long-tail crisis events like this one never to occur even as it makes their occurrence all but inevitable. 


\section{The future for working people}

The future for labor looks bleak. As Dani Rodrik and Stephanie Stantcheva argue, firms will continue to find no reason to give workers a say in "decisions about employment, investment, and innovation," with the result that an increasingly underemployed workforce will be left to deal with legacies of "broken families, substance abuse, and crime" in societies marred by "declining trust in government, experts, and institutions." 50 Facing up to another decade of labor insecurity will be particularly difficult for workers under forty years of age, for whom the 2008 global crisis came at an early point in their working lives. Valerio Lofoco, a thirty-one-year-old university graduate who has been waiting tables and delivering food to get by, told the Financial Times, "I was in my twenties when the economic crisis hit in 2008. This is the second global crisis facing my generation since I entered the job market." 51 How can workers like Lofoco be expected to face down another lost decade? The last crisis had a long-term negative effect on their lifetime earnings. ${ }^{52}$ The present crisis will be more punishing.

Meanwhile, the climate crisis is likely to deliver its own economic shocks before a full recovery from the pandemic crisis is achieved. Acknowledging the impossibility of continuing business as usual, even the World Economic Forum in Davos is calling for a "Great Reset" of global capitalism in response to the COVID-19 crisis. $^{53}$ However, governments are unlikely to enact the changes that a true reset would necessitate-above all clawing back wealth from the world's richest families to invest in health, housing, food, and energy security for the world's poor. Increasing the autonomy of those with the least economic and political power at the expense of those with the greatest will be a hard sell even with Davos's blessing. Still, economic stagnation and high levels of social inequality remain a potent brew. Over the proceeding decade, many countries have seen peaceful protest movements give way to more directly confrontational struggles. ${ }^{54}$ We can expect more of the same in the 2020 s.

\section{NOTES}

1. Research for this contribution is part of the Cluster of Excellence "Contestations of the Liberal Script" (EXC 2055, Project-ID: 390715649), funded by the Deutsche Forschungsgemeinschaft (DFG, German Research Foundation).

2. José Antonio Ocampo and Tomasso Faccio, "Making Multinationals and the Wealthy Pay," Project Syndicate, June 30, 2020. On secular stagnation and COVID-19, see for example Joseph Stiglitz et al., "How the Economy Will Look After the Coronavirus Pandemic," Foreign Policy, April 15, 2020.

3. World Bank, Global Economic Prospects (Washington, DC, 2020), 17.

4. Ibid., 5.

5. UNCTAD, Global Trade Update (Geneva, 2020), 2.

6. World Bank, Global Economic Prospects, 14.

7. Ibid., 15 .

8. Ibid., 14.

9. Gabriel Mathy, “The First Services Recession,” Phenomenal World, March 25, 2020. 
10. ILO, "COVID-19 and the World of Work, Fifth Edition," 6.

11. United Nations Department of Economic and Social Affairs, World Urbanization Prospects, 2018 Revision.

12. Ibid.

13. See Annie Wilkinson, "Local response in health emergencies: key considerations for addressing the COVID-19 pandemic in informal urban settlements," Environment and Urbanization, May 5, 2020.

14. David Grigg, "Agriculture in the World Economy: an Historical Geography of Decline," Geography 77 (3, 1992): 221.

15. Dani Rodrik, "Premature Deindustrialization," Journal of Economic Growth 21 $(1,2016)$.

16. UN Industrial Development Organization, Industrial Development Report 2018 (Vienna, 2018), 166.

17. ILO, ILOSTAT database, 2020 edition.

18. Ibid.

19. Ibid.

20. See David Blanchflower, Not Working: Where Have All the Good Jobs Gone? (Princeton, 2019).

21. ILO, "COVID-19 and the World of Work, Fifth Edition," 7.

22. Lance Lambert, " 45.7 million have filed for unemployment during the pandemicgreater than the combined population of 23 states," Fortune, June 18, 2020.

23. BLS, "Employment status of the civilian population by sex and age," July 2, 2020.

24. Jason Faberman and Aastha Rajan, "Is the Unemployment Rate a Good Measure of People Currently Out of Work?" Chicago Fed Insights, May 5, 2020.

25. For a comparison of the US and European employment responses, see Peter S. Goodman, Patricia Cohen, and Rachel Chaundler, "European Workers Draw Paychecks. American Workers Scrounge for Food." New York Times, July 3, 2020.

26. Eurostat, "News Release: Euro Indicators," July 2, 2020.

27. Jonathan Rothwell, "The Effects of COVID-19 on International Labor Markets: an Update," Brookings, May 27, 2020.

28. Silvia Amaro, "Europe's Job Retention Schemes Have Created 9 Million 'Zombie Jobs,' Analyst Warns," CNBC, June 23, 2020.

29. World Bank, Global Economic Prospects, 36.

30. See Aaron Benanav, "The Origins of Informality: The ILO at the Limit of the Concept of Unemployment," 14 (1, 2019): 107-25.

31. Raul Dancel, "Philippines' Unemployment Rate at Record High in April," The Straits Times, June 6, 2020.

32. ILO, "COVID-19 and the World of Work, Third Edition," ILO Monitor, April 29, $2020,1$.

33. Liz Sly, "Hunger Could Be More Deadly than Coronavirus in Poorer Countries," Washington Post, May 214, 020. Some analysts have suggested that poorer countries should avoid or quickly end pandemic lockdowns, based on the assumption that their younger populations should experience fewer COVID-19 deaths. However, populous countries like Brazil and Indonesia, where the virus is spreading rapidly, have seen many excess deaths, likely due to a higher prevalence of chronic illnesses and lack of access to intensive medical care. See Patrick GT Walker et al, "The Impact of COVID-19 and Strategies for Mitigation and Suppression in Low- and Middle-Income Countries," Science, 369 (6502, 2020): 413-22.

34. UN, "COVID-19 Fast Becoming Protection Crisis, Guterres Warns Security Council," UN News, July 2, 2020.

35. Anna Gross, "Silver Bullet to Beat COVID-19 Unlikely, Warns UK Vaccine Chief," Financial Times, July 29, 2020.

36. UN, "Hard Times Forecast for Global Job Recovery in 2020, Warns UN Labour Agency Chief," UN News, June 30, 2020.

37. Ibid.

38. UN Department of Economic and Social Affairs, World Economic Situation and Prospects: June 2020, Briefing No. 138, June 1, 2020.

39. World Bank, World Development Indicators, 2020.

40. Ibid.

41. Ibid. 
42. World Bank, Global Economic Prospects, 33.

43. Óscar Jordá, Sanjay R. Singh, and Alan M. Taylor, "Longer-run Economic Consequences of Pandemics," NBER Working Paper 26934, 2020.

44. See Robert Brenner, Economics of Global Turbulence (London, 2006), as well as Aaron Benanav, Automation and the Future of Work (London, 2020).

45. Agriculture is additionally burdened by the fact that the demand for farming products rises slowly even when agricultural prices fall dramatically, a regularity known as Engel's Law.

46. See, for example, William J. Baumol et al., The Cost Disease: Why Computers Get Cheaper and Health Care Doesn't (New Haven, CT, 2013).

47. See Aaron Benanav, "Crisis and Recovery," Phenomenal World, April 3, 2020.

48. See, for example, Rokhaya Diallo, "France's COVID-19 Failures Are the Result of Decades of Austerity," Al Jazeera, April 20, 2020.

49. See Jan Dutkiewicz, Astra Taylor, and Troy Vettese, "The Covid-19 pandemic shows we must transform the global food system," The Guardian, April 16, 2020.

50. Dani Rodrik and Stefanie Stantcheva, "The Post-Pandemic Social Contract," Project Syndicate, June 11, 2020.

51. Martin Arnold and Davide Ghiglione, "Europe's Young Feel Chill of Frozen Labour Market," Financial Times, June 16, 2020.

52. Philip Oreopoulos, Till von Wachter, Andrew Heisz, "The Short- and Long-Term Career Effects of Graduating in a Recession," American Economic Journal: Applied Economics, 4 (1, 2012): 1-29.

53. Sam Meredith, "Pandemic Must Lead to Real Change to Avoid Risk of Conflicts and Revolutions, WEF Founder Says," CNBC, July 13, 2020.

54. See Jack Shenker, "This Wave of Global Protest Is Being Led by the Children of the Financial Crash," Guardian, October 29, 2019. 